\title{
뇌신경세포에서 $\mathrm{tPA}$ 에 의한 $\mathrm{MMP}$ 의 발현 조절에 관한 연구
}

고운철 · 이선령*

제주대학교 생물학과

Received April 23, 2009 / Accepted May 4, 2009

Study on tPA-mediated MMP Regulation in Rat Neuronal Cells. Woon-Chul Ko and Sun-Ryung Lee*. Department of Biology, Jeju National University, Jeju 690-756, Korea - Tissue plasminogen activator (tPA) is very useful for dissolving the clots of blood, however, the use of tPA is limited to only $3-5 \%$ of ischemic stroke patients because of the narrow therapeutic time windows and negative side effects. Previous evidences suggest that limitation of tPA in thrombolytic therapy may be related to the upregulation of MMPs. However, little is known about the regulatory mechanism. In this study, we examined the role of tPA on MMP upregulation in rat neuronal cells. tPA $(5 \mu \mathrm{g} / \mathrm{ml})$ increased MMP-9 levels of neuronal cells in a time dependent manner. Hypoxia/reoxygenation amplified tPA-induced MMP-9 levels significantly. Pretreatment with JNK inhibitor SP600125 reduced the MMP-9 response. These results suggest that tPA can upregulate MMPs in neuronal cells and that JNK kinase may be involved.

Key words : Tissue plasminogen activator, matrix metalloproteinase, stroke, thrombolytic therapy

\section{서 론}

뇌졸중(stroke)은 뇌에 혈액을 공급하는 혈관이 막히거나 터 져서 생기는 뇌손상으로 여러 합병증의 결과물로서도 나타날 수 있다. 뇌졸중은 뇌혈관의 막힘으로 오는 뇌경색(ischemic stroke)과 뇌파열에 의한 뇌출혈(hemorrhagic stroke)로 구분 된다. 뇌졸중 치료에 사용되는 Tissue plasminogen activator (tPA)를 이용한 혈전용해 치료법(thrombolytic therapy)은 plasminogen을 plasmin으로 활성화시켜 혈액응고(clot)를 용 해시키는 $\mathrm{tPA}$ 의 1 차적인 기전에 기초를 둔 치료로서 혈관재관 류(vascular reperfusion)의 관점에서 매우 긍정적이고 효과적 인 치료법이다. 그러나 $\mathrm{tPA}$ 의 사용은 3 시간 이내에 이루어져야 되고 때때로 심각한 출혈(intracerebral hemorrhage $(\mathrm{ICH}))$ 이 나 부종(edema) 같은 부정적인 부작용을 야기한다는 점에서 위험률이 높아 실제 $5 \%$ 미만의 환자들에만 제한적으로 적용되 고 있다[3,9,14].

Matrix Metalloproteinases (MMPs)는 아연의 결합부위를 가지고 있는 endopeptidases로서 이들의 비정상적인 조절로 인한 불균형은 중추신경계에서 알츠하이머병(Alzheimer's disease)나 뇌경색(ischemia), 뇌출혈(hemorrhage) 같은 뇌질 환에 중요한 역할을 하는 것으로 알려져 있다[2,8,13]. $\mathrm{MMP}$ 의 불균형적인 활성화는 신경세포와 성상세포 주변의 물질들, basal lamina, blood vessels 사이의 상호작용을 중재하는 세포 외기질의 분해를 야기하게 되고 이로 인해 세포와 세포, 세포 와 기질사이의 신호전달체계의 변화와 함께 혈관벽을 약화시 켜 신경혈관계(neurovascular unit)의 항상성을 무너지게 한

*Corresponding author

Tel : +82-64-754-3522, Fax : +82-64-756-3541

E-mail : srlee@jejunu.ac.kr
다[1,8]. 실험적인 뇌졸중 모델에서, 임상의 환자에 있어서 $\mathrm{MMPs}$ 의 발현량은 현저히 증가되고 $\mathrm{MMPs}$ 저해제의 처리는 뇌혈관장벽(Brain-Blood Barrier, BBB)의 leakage, edema, infarction을 억제하였다[11]. tPA가 심각한 출혈이나 부종 같은 부작용을 야기하여 사용이 제한되어지는 원인도 $\mathrm{MMP}$ 에 의 한 작용과 관련이 있는 것으로 보여진다. $\mathrm{tPA}$ 의 처리는 embolic focal stroke모델에서 MMP-9의 발현량의 증가 뿐 아니 라 출혈(hemorrhage)을 유발하고 BBB 붕괴를 일으키는 반면, $\mathrm{MMP}$ 억제제의 처리는 출혈의 심각성을 현저하게 줄이는 것 으로 보고되어 있다[6,10,11].

따라서 본 연구에서는 in vitro system에서 뇌졸중 치료시 임상적으로 상반된 효과를 야기하는 $\mathrm{tPA}$ 의 효과가 $\mathrm{MMP}$ 의 불균형적인 활성 조절과 어떠한 연관성이 있는지를 알아보기 위해 뇌신경세포를 이용하여 $\mathrm{tPA}$ 의 단독처리 및 저산소상태 에서 $\mathrm{tPA}$ 가 $\mathrm{MMP}$ 활성도에 미치는 효과 및 조절 기전을 조사 하였다.

\section{재료 및 방법}

세포 배양

뇌신경세포는 임신 17 주된 배의 뇌피질에서 분리하였다. 세 포 현탁액은 poly-D-lysine이 코팅된 배양접시에 심어 2\% B27, glutamic acid, glutamine이 포함된 neurobasal medium (NBM)으로 10일 동안 배양하였다. 2일에 한번씩 cytosine이 포함된 $2 \% \mathrm{~B} 27 \mathrm{NB}$ 배지로 교환해 주었고 실험시작 1 일 전 $0.1 \%$ $\mathrm{B} 27 \mathrm{NB}$ 배지로 교환하여 안정화시킨 후 실험에 사용하였다.

\section{Hypoxia/Reoxygenation}

저산소상태(hypoxia)는 일정 농도의 세포가 심겨진 96 well 
또는 6 well 배양접시를 $90 \% \mathrm{~N} 2 / 5 \% \mathrm{CO} / 5 \% \mathrm{H} 2$ 를 주입한 저 산소배양기(hypoxia chamber)로 옮겨 밀폐된 공간에서 4시간 동안 유지하였고 이어 일반적인 $\mathrm{CO} 2$ 세포 배양기로 옮겨 16 시간동안 재관류 (re- oxygenation) 시켰다.

\section{Gelatin Zymography}

처리 24시간 후 원심분리를 통해 모아진 배지는 TCA 침전 법을 이용하여 농축시켜 $1 \mathrm{mg} / \mathrm{ml}$ gelatin이 포함된 $10 \%$ SDS-polyacrylamide gels에 전기영동 하였다. $2.7 \%$ Triton X-100 용액에서 1시간 반응하고 $50 \mathrm{mM}$ Tris base, $40 \mathrm{mM}$ $\mathrm{HCl}, 200 \mathrm{mM} \mathrm{NaCl}, 5 \mathrm{mM} \mathrm{CaCl}$, and $0.2 \%$ Briji 35를 포함한 developing buffer에서 20 시간 $37^{\circ} \mathrm{C}$ 항온조에서 반응시킨 후 Coomassie blue로 염색하여 MMP 활성도를 비교하였다. 상대 적인 MMP 활성도는 $\mathrm{NIH}$ image analysis software을 이용하 여 정량화하였다.

\section{결과 및 고찰}

지난 10 여 년 동안 $\mathrm{FDA}$ 의 승인을 받아 뇌졸중 치료에 사용 되는 $\mathrm{tPA}$ 는 뇌경색부위의 뇌조직을 재관류를 통해 회복시킨 다는 점에서 매우 효과적이지만 발병한지 3시간이후 사용을 하게 되면 상해, 부종, 출혈과 같은 부작용이 나타나 위험률이 상당히 높아지게 된다 $[3,9,14]$. 이전의 여러 보고들에 의하면 이러한 현상은 뇌신경혈관계(neurovascular unit)에서 tPA가 유도하는 $\mathrm{MMP}$ 의 불균형 조절(MMP dyregulation)과 관련이 있는 것으로 보여진다[6,10,11]. 동물을 이용한 focal cerebral ischemia모델에서 tPA의 주입은 MMP 발현량을 증가시켰고 증가된 $\mathrm{MMP}$ 의 활성은 basal lamina나 뇌혈관장벽(BBB)의 투 과성을 증대시켜 부종이나 혈관벽 파열을 유도하였다[11]. $\mathrm{MMP}$ 의 증가된 활성은 ischemia 동물 모델에서 뿐만 아니라 혈관내피세포를 이용한 저산소유발 모델에서도 확인되었고 cell free system하에서 기질 물질의 하나인 fibronectin을 분절 화를 유도하는 것으로 보고되어 있다[7]. 그러나 in vitro system에서 저산소증이 유발된 상태에서 tPA가 나타내는 효과와 그 조절 기전에 대한 연구는 거의 전무한 실정이다. 따라서 본 연구에서는 $\mathrm{tPA}$ 에 의해 유도될 수 있는 부작용이 $\mathrm{MMP}$ 의 활성증가에 의한 것인지, 어떠한 작용기전을 통해 조절 될 수 있는지를 알아보기 위해 임신 17 주된 쥐의 배에서 적출한 뇌 피질에서 뇌신경혈관계를 구성하는 신경세포를 분리, 배양하 여 $\mathrm{tPA}$ 에 의한 $\mathrm{MMP}$ 발현량을 조사하였다. 그 결과 농도 의존 적으로 $(1-5 \mu \mathrm{g} / \mathrm{ml}) \mathrm{tPA}$ 가 유도하는 MMP의 발현량은 증가되 는 양상을 보였고(Fig. 1A) 처리한 모든 농도에서 세포독성은 관찰되지 않았다(data not shown). 시간별에 따른 변화양상은 1 시간 이후부터 $\mathrm{MMP}$ 의 활성을 확인 할 수 있었고 6 시간째에 최대의 활성을 보여 24시간까지 지속되는 양상을 보였다 (Fig. 2A). In vitro system에서 뇌경색의 효율을 그대로 모방할
(A)

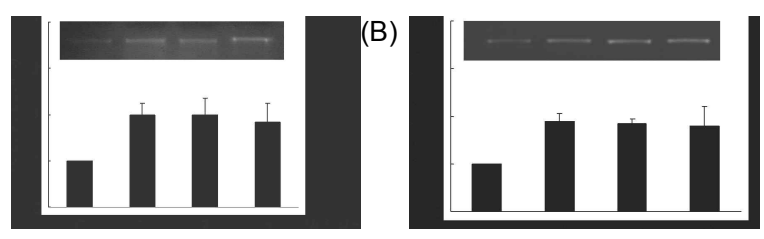

Fig. 1. The effects of tPA on MMPs regulation in rat cortical neuronal cells. Gelatin zymography and quantitative analysis show tPA induces MMP upregulation in a dose dependent manner (A) and in a time dependent manner (B). Values are means \pm S.D. from three independent experiments.
(A)

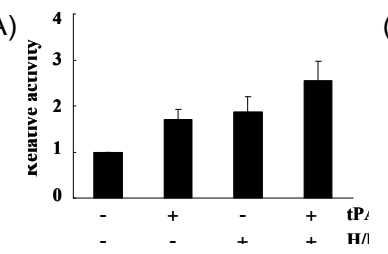

(B)

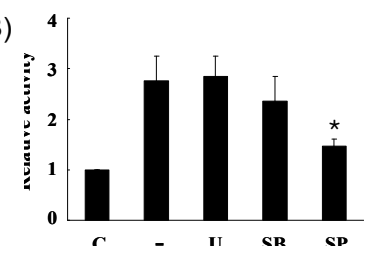

Fig. 2. (A) Quantitative analysis of MMP shows that (A) H4/R20 plus $5 \mu \mathrm{g} / \mathrm{ml}$ tPA amplify MMP levels compared each single treatment of H4/R20 or tPA, and (B) Pretreatment with SP600126 (SP) significantly reduces the H/R plus tPA-induced MMP response. Values are means \pm S.D. from three independent experiments. H4/R20, 4 hrs hypoxia and 20 hrs reoxygenation; U, U0126; SB, SB203580; SP, SP600125.

수 있는 4 시간의 저산소(hypoxia)에 따른 20시간의 재관류 (reoxygenation) 역시 약 2 배 정도의 $\mathrm{MMP}$ 의 활성 증가를 보 여주었다(Fig. 2A). tPA 이용한 thrombolytic therapy의 경우 뇌경색이 진행되고 있는 환자에 적용되어지므로 임상적인 치 료시기와 유사한 조건을 맞추기 위해 4 시간의 저산소 상태 후에 $5 \mu \mathrm{g} / \mathrm{ml} \mathrm{tPA}$ 를 처리하여 재관류 시켜주었다. Fig. 2A에 서 보여 지듯이 함께 처치된 경우 단독 처리된 $\mathrm{tPA}$ 나 저산소상 태 $(\mathrm{H} / \mathrm{R})$ 의 효과에 비해 월등히 증가된 MMP의 활성을 관찰 할 수 있었다. 이는 저산소상태로 인해 유도된 활성화된 MMP 가 기저막이나 뇌혈관벽을 약하게 만든 상태에서 $\mathrm{tPA}$ 의 직접 적인 처리는 $\mathrm{MMP}$ 의 활성을 증폭시켜 이들의 손상을 보다 빨리 가속화시키고 뇌신경혈관계를 구성요소들의 항상성 파 괴를 야기할 것으로 생각된다. 다음으로 $\mathrm{tPA}$ 의 $\mathrm{MMP}$ 발현조 절 기전을 알아보기 위해 3 가지 MAP kinase 경로와의 관련성 을 검토하였다. U0126 (ERK inhibitor), SB203580 (p38 kinase inhibitor), SP600125 (JNK inhibitor) 각각을 30분 전 처리한 후 $\mathrm{tPA}$ 와 저산소가 유도하는 $\mathrm{MMP}$ 활성도를 비교 분석한 결 과 U0126과 SB203580 처리군에서는 대조군과 유사한 양상을 보인 반면, SP600125를 처리한 실험군에서는 MMP 활성이 현 저히 감소된 것을 확인할 수 있었다(Fig. 2B). 이는 JNK 신호전 달경로가 발현조절에 중요한 작용을 하고 있음을 보여주는 것이다. 물론 세포의 타입에 따라 다르긴 하지만 뇌신경혈관 계 세포들외의 많은 세포들에서 보고된 바에 따르면 $\mathrm{MMP}$ 의 
발현 조절 기전은 주로 MAP kinase 경로에 의존적인 것으로 보인다. THP-1이나 HL-60 같은 monocytic 세포에서는 ERK 경로를 통해 MMP발현이 조절되고 OVCAR-3 세포에서는 $\mathrm{JNK}$ 경로가 관여하고 있다[4,5]. 이는 $\mathrm{MMP}$ 발현이 전사조절 수준에서 $\mathrm{MMP}$ 의 프로모터 부위에 존재하는 AP-1에 의해 조 절되고 그 상위신호경로에서 작용하는 MAP kinase 계열의 신호전달과정이 중요한 역할을 수행하는 것으로 보여진다.

tPA에 의한 MMP활성 증가는 저산소상태가 유지될 때 더 욱 가속화되며 이는 JNK신호전달 경로를 통해 조절되어지는 결과들로 보아 장시간 뇌허혈에 노출된 환자에게 $\mathrm{tPA}$ 가 처치 될 경우 출혈이나 부종 같은 부작용을 일으키는데 있어서 $\mathrm{MMP}$ 의 작용이 중요한 역할을 할 것으로 사료된다. 특히, JNK 억제재의 경우 $\mathrm{MMP}$ 불균형을 조절할 수 있는 인자로서 구체 적인 기전을 밝혀낸다면 더 효과적인 뇌졸중 치료법을 개발하 는데 도움이 되리라 생각된다.

\section{요 약}

뇌졸중 치료에 사용되는 tPA는 탁월한 혈전 용해 효과를 보이고 있어 혈액의 흐름을 용이하게 하는데 중요한 역할을 한다. 그러나 tPA 치료법은 매우 짧은 시간 내에 사용해야하는 단점과 출혈, 부종과 같은 여러 가지 부작용이 수반될 수 있기 때문에 매우 제한적이다. 이전의 실험 결과에 따르면 $\mathrm{tPA}$ 의 이러한 양면적인 현상은 $\mathrm{MMP}$ 의 활성 조절과 관련이 있는 것으로 보고되어 있으나 세포시스템을 활용한 이들의 직접적 인 효과나 조절 기전에 대한 연구는 거의 알려져 있지 않다. 본 연구는 임상에서 사용되는 $\mathrm{tPA}$ 의 부정적인 효과를 극복하 기 위한 방안을 모색하고자 $\mathrm{tPA}$ 와 $\mathrm{MMP}$ 활성과의 조절 기전 을 살펴보았다. 랫트의 뇌로부터 추출한 신경세포에서 $\mathrm{tPA}$ 의 처리는 $\mathrm{MMP}$ 의 발현을 촉진시켰고 저산소상태에서 $\mathrm{tPA}$ 에 의 한 $\mathrm{MMP}$ 활성 증가가 더욱 가속화되었으며 JNK 신호전달 경 로를 통해 조절되는 것을 확인하였다.

\section{감사의 글}

이 논문은 2006년 정부(교육인적자원부)의 재원으로 한국 학술진흥재단의 지원을 받아 수행된 연구임(KRF-2006-331E00216).

\section{Reference}

1. del Zoppo, G. J. and T. Mabuchi. 2003. Cerebral microvessel responses to focal ischemia. J. Cereb. Blood Flow Metab. 23, 879-894.
2. Guo, S. and E. H. Lo. 2008. Dysfunctional cell-cell signaling in the neurovascular unit as a paradigm for central nervous system disease. Stroke 40 (3suppl), s4-7.

3. Hacke, W., T. Brott, L. Caplan, D. Meier, C. Fieschi, R. von Kummer, G. Donnan, W. D. Heiss, N. G. Wahlgren, M. Spranger, G. Boysen, and J. R. Marler. 1999. Thrombolysis in acute ischemic stroke: controlled trials and clinical experience. Neurology 53, S3-S14.

4. Heidinger, M., H. Kolb, H. W. Krell, M. Jochum, and C. Ries. 2006. Modulation of qutocrine TNF-alpha stimulated matrix metalloproteinase- 9 expression by mitogen activated protein kinases in THP-1 monocytic cells. J. Biol. Chem 387, 69-78.

5. Kim, K. C. and C. H. Lee. 2005. MAP kinase activation is required for the MMP-9 induction by TNF-stimulation. Arch Pharmacol. Res. 28, 1257-1262.

6. Lapchack, P. A., D. M. Arujo, S. Pakola, D. Song, J. Wei, and J. A. Zivin. 2002. microplasmin: a novel thrombolytic that improves behavioral outcome after embolic strokes in rabbits. Stroke 33, 2279-2284.

7. Lee, S. R. and E. H. Lo. 2004. Induction of caspase-mediated cell death by matrix metalloproteinases in cerebral endothelial cells after hypoxia-reoxygenation. J. Cereb. Blood Flow Metab. 24, 720-727.

8. Lo, E. H., T. Dalkara, and M. A. Moskowitz. 2003. Mechanism, challenges and opportunites in stroke. Nat. ReV. Neurosci. 4, 399-415.

9. Rosell, A., C. Foerch, Y. Murata, and E. H. Lo. 2008. Mechanisms and markers for hemorrhagic transformation after stroke. Acta Neurochir. Suppl. 105, 173-178.

10. Sumii, T. and E. H. Lo. 2002. Involvement of matrix metalloproteinase in thrombolysis-associated hemorrhagic transformation after embolic focalischemia in rat. Stroke 33, 831-836.

11. Tsuji, K., T. Aoki, E. Tejima, K. Arai, S. R. Lee, D. N. Atochin, P. L. Huang, X. Wang, J. Montaner, and E. H. Lo. 2005. Tissue plasminogen activator promotes matrix metalloproteinase-9 upregulation after focal cerebral ischemia. Stroke 36, 1954-1959.

12. Wang, X., A. Rosell, and E. H. Lo. 2008. Targeting extracellular matrix proteolysis for hemorrhagic complications of tPA stroke therapy. CNS Neurol. Disord Drug Targets 7, 235-242.

13. Wang, X., K. Tsuji, S. R. Lee, M. M.. Ning, K. L. Furie, A. M. Buchan, and E. H. Lo. 2004. Mechanisms of hemorrhagic transformation after tissue plasminogen activator reperfusion therapy for ischemia stroke. Stroke 35 (suppl1), 2726-2730.

14. Wardlaw, J. M., P. A. Sandercock, and E. Berge. 2003. Thrombolytic therapy with recombinant tissue plasminogen activator for acute ischemic stroke: where do we go from here? Acumulative meta-analysis. Stroke 34, 1437-1442. 